\title{
Akibat Hukum Berlakunya Perma Nomor 02 Tahun 2012 Tentang Penyesuaian Batasan Tindak Pidana Pencurian Ringan Dan Jumlah Denda Dalam KUHP
}

\section{Legal Consequences of the Applicability of Perma Number 02 of 2012 concerning Adjustment of Limits on the Crime of Minor Theft and the Amount of Fines in the Criminal Code}

\author{
Hasiholan Naibaho, Isnaini* \& Marlina \\ Program Studi Magister Ilmu Hukum, Universitas Medan Area Indonesia \\ Diterima: 11 Juni 2021; Direview: 01 Agustus 2021; Disetujui: 01 Oktober 2021 \\ *Coresponding Email: isnaini@staff.uma.ac.id
}

\begin{abstract}
Abstrak
Dengan menerbitkan Peraturan Mahkamah Agung Nomor 2 Tahun 2012 Tentang Batasan Tindak Pidana Ringan dan Jumlah Denda dalam KUHP guna menyelesaikan tindak pidana ringan. Setelah terbitnya PERMA tersebut, timbul masalah baru dikarenakan PERMA tersebut tidak digunakan dalam penyelesaian perkara tindak pidana ringan. Hal ini menyebabkan Ketidakpastian Hukum setelah terbitnya PERMA No. 2 Tahun 2012. Tesis ini menggunakan penelitian hukum Normatif, yaitu penelitian yang mengacu kepada norma-norma hukum yang terdapat dalam peraturan perundang-undangan yang berlaku sebagai pijakan normatif. Kaidah hukum batasan tindak pidana ringan dan jumlah denda dalam KUHP dengan lahirnya Peraturan Mahkamah Agung Nomor 02 Tahun 2012 yaitu: Kedudukan Hukum Peraturan Mahkamah Agung Nomor 2 Tahun 2012 secara substansi adalah berkaitan penyesuaian batasan tindak pidana ringan dan jumlah denda. Implementasi hukum terhadap tindak pidana pencurian ringan setelah lahirnya Peraturan Mahkamah Agung Nomor 02 Tahun 2012 tentang tindak pidana ringan adalah sebagai berikut: Keberadaan Perma No. 2 Tahun 2012 adalah sebagai Kebijakan Kriminal dan selama ini kebijakan kriminal dipahami sebagai ranah Sistem Peradilan Pidana (SPP) yang menerapkan reprentasi dari negara. Selain itu, kebijakan kriminal juga lebih dipahami sebagai cara yang ditempuh untuk menegakkan hukum dalam rangka penanggulangan kejahatan. Kendala yang dihadapi oleh aparat penegak hukum Kepolisian. Kendala dalam penegakan hukum terjadi apabila ada ketidakserasian antara pasangan nilai dan ketidakserasian ini bisa disebabkan oleh: Pemahaman pihak Kepolisian tentang Perma tersebut, Keberanian aparat Kepolisan dengan tidak tumpang tindih, Sosialisasi Perma tersebut dan Membentuk Kultur masyarakat.
\end{abstract}

Kata Kunci: Akibat Hukum; Penyesuaian Batasan; Tindak Pidana Ringan.

\begin{abstract}
By issuing Supreme Court Regulation Number 2 of 2012 concerning Limits of Minor Crimes and the Amount of Fines in the Criminal Code in order to resolve minor crimes. After the issuance of the PERMA, a new problem arose because the PERMA was not used in the settlement of minor criminal cases. This causes legal uncertainty after the issuance of PERMA No. 2 of 2012. This thesis uses normative legal research, namely research that refers to legal norms contained in laws and regulations that apply as a normative footing. The legal rules limiting minor crimes and the amount of fines in the Criminal Code with the issuance of Supreme Court Regulation Number 02 of 2012 namely: Legal Position Supreme Court Regulation Number 2 of 2012 substantially relates to adjustments to the limits of minor crimes and the amount of fines. The implementation of the law against the crime of minor theft after the issuance of the Supreme Court Regulation Number 02 of 2012 concerning minor crimes is as follows: The existence of Perma No. 2 of 2012 is a Criminal Policy and so far criminal policy is understood as the domain of the Criminal Justice System (SPP) which implements the representation of the state. In addition, criminal policy is also better understood as a way to enforce the law in the context of crime prevention. Constraints faced by law enforcement officers of the Police. Constraints in law enforcement occur when there is a discrepancy between value pairs and this discrepancy can be caused by: understanding of the police regarding the regulation, the courage of the police officers without overlapping, socialization of the regulation and shaping community culture
\end{abstract}

Keywords: Legal Consequences; Adjustment of Limits; Minor Crimes.

How to Cite: Naibaho, H., Isnaini., \& Marlina. (2021). Akibat Hukum Berlakunya Perma Nomor 02 Tahun 2012 Tentang Penyesuaian Batasan Tindak Pidana Pencurian Ringan Dan Jumlah Denda Dalam KUHP. Journal of Education, Humaniora and Social Sciences (JEHSS). 4 (2): 998-1007. 


\section{PENDAHULUAN}

Hukum di Indonesia sampai saat ini masih beraneka ragam (pluralistis). Pandangan demikian tidak dapat dipersalahkan, apalagi kita sebagai suatu bangsa sangat menjunjung tinggi Bhineka Tunggal Ika. Termasuk dalam makna hukum yang dimaksud dalam kutipan tersebut, sudah barang tertentu adalah Hukum Pidana. Banyak peristiwa yang terjadi di tengah-tengah masyarakat mengenai carut marutnya Penegakan Hukum Pidana di Indonesia, padahal Indon esia adalah Negara Hukum, tetapi dalam aplikasinya tidak mencerminkan sebagai negara hukum, bahkan banyak tindakan aparatur penegak hukum bertentangan dengan hukum baik dalam proses tahap penyelidikan, penyidikan, penuntutan, pemeriksaan di sidang Pengadilan maupun dalam pelaksanaan eksekusi (Achjani, 2017).

Karakteristik Penegakan Hukum Pidana di Indonesia sangat unik dan multidimensi serta destruktif sebagaimana dilihat penegakan di berbagai kasus pidana diantaranya kasus kejahatan korupsi, kasus kejahatan illegal loging, kasus kejahatan perampokan Bank, kasus kejahatan terorisme, kasus kejahatan kelautan, kasus kejahatan Cyber Crime, kejahatan narkotika dan lainlain sebagainya, dimana penegakan hukum terhadap para pelaku kejahatan banyak sekali terjadi penyimpangan (Deviation) dari aturan hukum pidana, sehingga orang yang seharusnya tidak bersalah bisa jadi tersangka, demikian sebaliknya orang yang seharusnya menurut hukum bersalah bebas dari jeratan hukum (Ediwarman, 2014; Hananta, 2017).

Pencarian mengenai pengertian tindak pidana ringan pun semakin sulit, dimana dalam KUHP sendiri tidak mengaturnya. Adapun Pradjodikoro (2012) menyatakan bahwa dalam KUHP ada beberapa kejahatan mengenai harta benda (vermogendelicten), apabila kerugian yang diakibatkan tidak melebihi dua puluh lima rupiah, dinamakan kejahatan ringan (lichte misdren) dan hanya di ancam dengan hukuman seberat-beratnya hukuman Penjara 3 bulan.

Kejahatan ringan ini adalah: Pencurian ringan (Pasal 364), yakni apabila barang yang dicuri tidak berupa ternak (vee) dan apabila pencurian yang disertai pengerusakan tidak dilakukan dalam suatu rumah pediaman atau satu pekarangan tertutup, di mana ada berdiri satu rumah pendiaman (Purba, 2017). Penggelapan ringan (Pasal 373), yakni apabila barang yang digelapkan tidak berupa ternak. Penipuan ringan (Pasal 379), yakni apabila barang yang di dapat oleh si penipu tidak berupa ternak. Merusak barang orang lain (Pasal 407 ayat 1). Penadahan ringan (Pasal 482), yakni apabila barangnya diperoleh dengan pencurian ringan, penggelapan ringan, atau penipuan ringan.

Adapun beberapa diantaranya yang memberikan arah pengertian, atau konsep, atau kriteria tindak pidana ringan yakni:

Simanjuntak T: Bahwa tindak pidana ringan adalah tindak pidana yang diancam dengan pidana penjara atau kurungan paling lama tiga bulan dan/atau denda sebanyakbanyaknya Rp. 7.500,00 (tuju ribu lima ratus rupiah) dan penghinaan ringan, kecuali pelanggaran tertentu terhadap peraturan perundang-undangan lalu lintas jalan, sebagai petunjuk dalam penanganan perkara tindak pidana ringan sebagaimana diatur dalam pasal KUHP dan Peraturan perundang-undangan lainnya.

Hidayatullah: Bahwa dalam praktik hukum acara pidana dikenal dengan istilah Tipiring (Tindak Pidana Ringan) di mana merupakan singkatan dari istilah yang terdapat di dalam BAB XVI, Pemeriksaan di Sidang Pengadilan, Bagian ke enam Pemeriksaan Cepat, Paragraf I Acara Pemeriksaan Tindak Pidana Ringan, Kitab Undang-Undang Hukum Acara Pidana (KUHAP). Berdasarkan Pasal 205 ayat (1) KUHAP merumuskan kriteria tindak pidana ringan ialah perkara yang diancam dengan pidana penjara atau kurungan paling lama tiga bulan atau denda sebanyakbanyaknya Rp.7.500,00 (tujuh ribu lima ratus rupiah) dan penghinaan ringan kecuali yang ditentukan dalam paragraph 2 bagian ini. Sementara berdasarkan Peraturan Mahkamah Agung (PERMA) Nomor 2 Tahun 2012 tentang Penyesuaian Batasan Tindak Pidana Ringan dan jumlah denda dalam KUHP bahwa besaran nilai kerugian yang disebutkan pada Undang-Undang di atas sudah tidak sesuai 
dengan nilai tukar mata uang pada saat ini. Berdasarkan Pasal 2 ayat (2) PERMA ini menetapkan nilai kerugian sebesar Rp. 2.500.00,00 (dua juta lima ratus ribu rupiah). Dengan diterbitkannya PERMA Nomor 2 Tahun 2012 ini diharapkan adanya penanganan secara cepat proposional dengan pemeriksaan secara cepat pada kasus-kasus tindak pidana ringan yang diatur dalam KUHP, seperti: (i) pencurian ringan (Pasal 364), (ii) penggelapan ringan (Pasal 373), (iii) penipuan ringan oleh penjual (Pasal 384), (iv) perusakan ringan (Pasal 407 ayat (1) dan penadahan ringan (Pasal 484).

Sedangkan pengertian mengenai tindak pidana yang berdampak luar biasa (extra ordinary crime) adalah bentuk tindak pidana yang dapat mempengaruhi stabilitas dan keamanan masyarakat yang merusak lembaga-lembaga dan nilai-nilai demokrasi, nilai-nilai etika dan keadilan serta mengacaukan pembangunan yang berkelanjutan dan penegakan hukum (Rumokoy, 2017).

Untuk menerapkan Perma 02 tahun 2012 tersebut tidak hanya sebatas nilai barang yang dicuri juga kapan dan siapa pelakunya. Hal ini tentu perlu pengkajian dan sosialisasi lebih lanjut mengenai Perma tersebut agar tidak tumpang tindih dalam penerapannya sehingga restorasi hukum yang diharapkan tidak salah penerapannya.

Kasus tindak pidana ringan di Indonesia bukanlah sebuah kasus yang berat yang mampu menarik perhatian publik. Namun, pada kenyataannya kasus tindak pidana ringan saat ini banyak mendapatkan perhatian publik dikarenakan, hukum tidak memberikan nilai keadilan. Hukuman dan penyelesaian terhadap tindak pidana ringan disamakan dengan tindak pidana biasa. Hal tersebut menimbulkan keresahan di masyarakat dan di tanggapi positif oleh Mahkamah Agung dengan menerbitkan Peraturan Mahkamah Agung Nomor 2 Tahun 2012 Tentang Batasan Tindak Pidana Ringan dan Jumlah Denda dalam KUHP guna menyelesaikan tindak pidana ringan. Setelah terbitnya PERMA tersebut, timbul masalah baru dikarenakan PERMA tersebut tidak digunakan dalam penyelesaian perkara tindak pidana ringan.

Selain untuk mengikuti nilai-nilai keadilan yang hidup dalam masyarakat, pembedaan tindak pidana ringan dengan tindak pidana biasa dan tindak pidana berat adalah agar proses pemeriksaan perkara pidana tersebut dilaksanakan secara proporsional sesuai dengan kualitas tindak pidananya. Berdasarkan ketentuan Pasal 205 Undang-Undang Nomor 8 Tahun 1981 Tentang Hukum Acara Pidana (Lembaran Negara Republik Indonesia Tahun 1981 Nomor 76, Tambahan Lembaran Negara Nomor 3209, selanjutnya disingkat menjadi KUHAP) berbunyi “yang diperiksa menurut acara pemeriksaan tindak pidana ringan ialah perkara yang diancam dengan pidana penjara ataukurungan paling lama tiga bulan dan atau denda sebanyak-banyaknya tujuh ribu lima ratus rupiah dan penghinaan ringan kecuali yang ditentukan dalam paragraph 2 bagian ini "bahwa berdasarkan ketentuan Pasal tersebut maka tindak pidana ringan diperiksa dengan acara pemeriksaan cepat.

Dalam acara pemeriksaan cepat Pengadilan mengadili dengan hakim tunggal pada tingkat pertama dan terakhir, kecuali dalam hal putusan hakim menjatuhkan putusan pidana yang bersifat perampasan bagi kemerdekaan terdakwa, maka terdakwa dapat mengajukan banding. Penuntutan dalam acara pemeriksaan cepat dilakukan oleh penyidik atas kuasa penuntut umum. Selain itu terhadap tersangka atau terdakwa pelaku tindak pidana ringan tidak dilakukan penahanan karena ancaman pidana penjaranya dibawah lima tahun yakni paling lama tiga bulan. Berkaitan dengan masalah tersebut diatas, maka Mahkamah Agung membentuk Peraturan Mahkamah Agung Republik Indonesia Nomor 2 Tahun 2012 tentang Penyesuaian Batasan Tindak Pidana Ringan dan Jumlah denda dalam KUHP (selanjutnya disingkat menjadi PERMA No. 2 Tahun 2012).

Berdasarkan latar belakang di atas, maka penulis bermaksud untuk mengkaji lebih dalam mengenai batas nilai kerugian pada tindak pidana ringan yang ada di dalam KUHP, dan peran aparat penegak hukum (Kepolisian) dalam penegakan hukum terhadap tindak pidana ringan berdasarkan Peraturan Mahkamah Agung Nomor 02 Tahun 2012.

\footnotetext{
100 http://mahesainstitute.web.id/ojs2/index.php/jehss mahesainstitut@gmail.com 


\section{METODE PENELITIAN}

Penelitian ini akan dilakukan di Kantor Kepolisian Negara Republik Indonesia Daerah Sumatera Utara (Resor Labuhan Batu) yang terletak di jalan Mh. Thamrin No. 07 Rantauprapat. Penelitian ini menggunakan penelitian hukum Normatif, yaitu penelitian yang mengacu kepada norma-norma hukum yang terdapat dalam peraturan perundang-undangan yang berlaku sebagai pijakan normatif (Nurhaini, 2018).

Oleh karena jenis penelitian ini adalah metode penelitian hukum normatif, data yang diperoleh berasal dari studi kepustakaan dimana penulis memilah dan membaca kepustakaan yang berkaitan dengan masalah yang diteliti, dalam penelitian ini data yang digunakan adalah data sekunder.

Metode pendekatan yang digunakan dengan pendekatan perundang-undangan (Statute Approach) dan pendekatan normatif. Penelitian ini juga disebut dengan istilah pendekatan/penelitian doktrinal atau dikenal pula penelitian hukum normatif. Tahap penelitian yuridis normatif melalui studi kepustakaan. Seluruh data sekunder yang dipergunakan dalam penelitian ini dikumpulkan dengan studi kepustakaan (library research) (Zulyadi, 2020). Penelitian pustaka dimaksud merupakan penelitian bahan hukum primer yaitu peraturan perundang-undangan yang berkaitan dengan tindak pidana bermotif ringan.

Selain studi kepustakaan, maka penelitian ini memerlukan data pendukung yang diperoleh dengan wawancara dengan pihak Kepolisian, objek penelitian dengan Kepolisian Negara Republik Indonesia Daerah Sumatera Utara Resor Labuhan Batu (Sianturi, Dkk., 2020). Setelah bahan hukum terkumpul kemudian dilakukan analisis untuk mendapatkan argumentasi akhir yang berupa jawaban terhadap permasalahan penelitian. Untuk itu setidak-tidaknya dapat digunakan empat macam teknik analisi yakni: deskripsi, komparasi, evaluasi dan argumentasi. Data yang telah dikumpulkan dengan studi kepustakaan dan wawancara tersebut selanjutnya dianalisis dengan mempergunakan metode analisis kualitatif yaitu penelitian tentang riset yang bersifat deskriptif.

\section{HASIL DAN PEMBAHASAN}

\section{Kaidah Hukum Batasan Tindak Pidana Ringan dan Jumlah Denda Dalam KUHP Dengan} Lahirnya Peraturan Mahkamah Agung Nomor 02 Tahun 2012

Pengaturan Hukum Tentang Tindak Pidana Ringan dan Jumlah Denda Dalam KUHP. Kedudukan Peraturan Mahkamah Agung (PERMA) menjadi penting untuk dibahas karena dapat mempengaruhi penanganan perkara dalam Sistem Peradilan Pidana Terpadu di Indonesia (Noviansyah, Rifai, \& Dewi, 2018). PERMA sebagai produk hukum Mahkamah Agung pada dasarnya mengikat internal dan lembaga peradilan di bawahnya. Sedangkan dalam sebuah Sistem Peradilan Perdana Terpadu, pihak yang terlibat sebagai subsistem didalamnya adalah kepolisisan, kejaksaan, pegadilan, dan lembaga pemasyarakatan. Melihat kekuatan mengikat PERMA tersebut maka dalam suatu Integrated Criminal Justice System atau Sistem Peradilan Pidana Terpadu yang terikat oleh PERMA tersebut hannyalah Pengadilan.

Menyikapi ketidaksesuaian batasan tindak pidana ringan dan jumlah denda dalam KUHP dengan perkembangan yang ada, Mahkamah Agung RI pada tanggal 7 Februari 2012 menerbitkan Perma No. 2 Tahun 2012 Tentang Penyesuaian Batasan Tindak Pidana Ringan dan Jumlah Denda dalam KUHP. Untuk itu akan membahas masalah tentang dasar diterbitkannya, muatan, serta kedudukan dari Perma No. 2 Tahun 2012 tersebut. Hal ini penting untuk dikaji karena dengan keberlakuan Perma tersebut dalam praktik peradilan, dimana banyak praktisi maupun akademisi yang mempertanyakan kekuatan sebuah Perma untuk mengubah suatu ketentuan UndangUndang, dalam hal ini KUHP. Walaupun Mahkamah Agung sendiri dalam konsideran menimbang huruf e Perma No. 2 Tahun 2012 tersebut, secara jelas menyatakan bahwa: Perma ini sama sekali tidak bermaksud mengubah KUHP, Mahkamah Agung hanya melakukan penyesuaian nilai uang yang sudah sangat tidak sesuai dengan kondisi sekarang ini. Hal ini dimaksudkan untuk memudahkan penegak hukum khususnya hakim, untuk memberikan keadilan terhadap perkara yang diadilinya. 
Dasar Diterbitkannya PERMA No. 2 Tahun 2012 Tentang Penyesuaian Tindak Pidana Ringan dan Jumlah Denda Dalam KUHP. Tiga hal mendasar yang harus dipertimbangkan ketika kita berbicara tentang dasar diterbitkannya suatu peraturan perundang-undangan, agar suatu peraturan perundang-undangan dapat efektif mencapai tujuan hukum itu sendiri, ketiga hal tersebut adalah dasar yuridis, dasar sosiologis, dan dasar filosofis (Herman, Din, \& Ali, 2018).

Dasar yuridis berkaitan dengan pemberian legitimasi hukum. Ia muncul untuk menjawab kewenangan hukum apa/mana yang menjadi dasar untuk mengeluarkan suatu perundangundangan tertentu. Dasar yuridis ini diperlukan untuk menjamin terpenuhinya kepastian hukum, untuk mencapai cita-cita negara hukum yang dituangkan dalam Pasal 1 Ayat (3) UUD 1945. Menurut Asmah (2018) kepastian hukum merupakan perlindungan yustisiabel terhadap tindakan sewenang-wenang, yang berarti bahwa seseorang akan dapat memperoleh sesuatu yang diharapkan dalam keadaan tertentu.

Kepastian hukum itu harus menjadi nilai bagi setiap pihak dalam setiap kehidupan, di luar peranan negara itu sendiri dalam penerapan hukum legislasi maupun yudikasi. Setiap orang atau pihak tidak diperkenankan untuk bersikap tidak semena-mena (Sinaga, 2017). Kepastian hukum dituangkan dalam peraturan perundang-undangan yang seharusnya melindungi yustisiabel dari tindakan sewenang-wenang. Namun ketika peraturan perundang-undangan tersebut tidak lagi sesuai dengan perkembangan masyarakat, maka kecenderungan justru timbul kesewenangwenangan terhadap yustisiabel dalam bentuk pengabaian oleh pembentuk undang-undang, yang jika hal tersebut dibiarkan, dan pengadilan terus dengan begitu saja mengikutinya untuk sematamata mengejar kepastian hukum, maka pengadilan juga telah mengabaikan prinsip-prinsip keadilan, di sinilah muncul antinomi nilai antara keadilan dan kepastian hokum (Batu, Dkk, 2020).

Sebagai pelaku kekuasaan kehakiman, selain berwenang mengadili pada tingkat kasasi dan menguji peraturan perundang-undangan di bawah undang-undang terhadap undang-undang, Mahkamah Agung juga memiliki wewenang lainnya yang diberikan oleh undang-undang. Salah satu wewenang lain yang diberikan oleh undang-undang tersebut diatur dalam Pasal 79 undangundang tentang Mahkamah Agung yang menentukan bahwa Mahkamah Agung dapat mengatur lebih lanjut hal-hal yang diperlukan bagi kelancaran penyelenggaraan peradilan apabila terdapat hal-hal yang belum cukup diatur dalam Undang-Undang ini.

Dalam konsideran PERMA No. 2 Tahun 2012 disebutkan lima peraturan perundangundangan yang menjadi landasan yuridis, yaitu: (1) Pasal 24 UUD 1945 sebagaimana telah diubah dan ditambah dengan Perubahan keempat Tahun 2002; (2) UU No. 1 Tahun 1946 tentang Hukum Pidana (KUHP); (3) Perpu No. 16 Tahun 1960; (4) Perpu No. 18 Tahun 1960; dan (5) UU Mahkamah Agung.

\section{Kaidah Hukum PERMA No. 2 Tahun 2012 Tentang Penyesuaian Batasan Tindak Pidana Ringan dan Jumlah Denda dalam KUHP}

Sebagaimana diketahui bahwa Kitab Undang-Undang Hukum Pidan (KUHP) yang berlaku sekarang ini merupakan hasil adaptasi dari peraturan pidana yang berlaku pada masa HindiaBelanda. Keberlakuan KUHP tersebut kemudian disahkan melalui Undang-Undang No.1 Tahun 1946 tentang Peraturan Hukum Pidana Indonesia. Nilai objek perkara pada pasal-pasal tindak pidana ringan pada masa tersebut hanyalah sebesar Rp. 25,00 (dua puluh lima rupiah). Pada tahun 1960, pemerintah mengeluarkan dua Peraturan Pemerintah Pengganti Undang-Undang (PERPU) yang mengatur penyesuaian nilai objek perkara tersebut dan uang denda dalam KUHP.

PERPPU No.16 Tahun 1960 tentang Beberapa Perubahan dalam KUHP mengubah nominal objek perkara dalam pasal-pasal tindak pidana ringan menjadi Rp. 250,00 (dua ratus lima puluh rupiah). Pasal-pasal tindak pidana ringan yang dimaksud antara lain Pasal 364, 373, 379, 384, 407 ayat (1) dan 482 KUHP.

Sedangkan PERPPU No. 18 Tahun 1960 menyesuaikan nilai denda dalam KUHP menjadi 15 kali lipat. Akan tetapi, dalam kurun waktu semenjak PERPPU tersebut dikeluarkan hingga pada penghujung tahun 2011, nilai objek perkara dalam pasal-pasal tindak pidana ringan tersebut tidak pernah lagi diperbaharui. Oleh sebab itu, pasal-pasal yang dimaksud tersebut menjadi tidak http://mahesainstitute.web.id/ojs2/index.php/jehss mahesainstitut@gmail.com

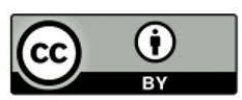


relevan dan efektif lagi untuk diterapkan. Beberapa kasus yang sempat muncul di media massa, seperti kasus pencurian buah kakao, pencurian sandal jepit, dan lain-lain dianggap kurang memenuhi rasa keadilan di masyarakat. Terhadap kasus-kasus tersebut, jaksa lebih cenderung menggunakan pasal pencurian biasa yang diatur dalam Pasal 362. Setiap pencurian dengan nilai barang di atas Rp. 250,00 (dua ratus lima puluh rupiah) dipandang sebagai pencurian biasa. Akan tetapi, dalam kasus-kasus tersebut sekalipun nilai barang yang dicuri lebih dari Rp.250,00 namun penanganannya terkadang dianggap tidak proporsional dengan perbuatannya.

\section{Penanganan Kasus Tindak Pidana Pencurian Ringan yang dilakukan oleh Polres Labuhan Batu Beserta Polsek Sejajaran}

Dalam pengananan kasus tindak pidana ringan yang dilakukan oleh Polres Labuhan Batu Beserta Polsek Sejajaran lebih mengutamakan penyelesaian secara kekeluargaan. Analisis peneliti menyimpulkan bahwa Kepolisian yang ada lebih mendahulukan penyelesaian tindak pidana ringan dengan cara kekeluargaan sehingga dalam penyelesaian dengan cara ini telah mendapatkan suatu kesepakatan antara pelapor dan terlapor maka kasus ini tidak lagi dilanjutkan dengan prosedur yang ada dan kasus ini dianggap telah selesai.

Adapun prosedur penanganan kasus tindak pidana ringan yang dilakukan Polres Labuhan Batu Beserta Polsek Sejajaran sebagai berikut:

Berdasarkan Peraturan Kepala Badan Pemelihara Keamanan Kepolisian Negara Republik Indonesia Nomor 6 Tahun 2011 tentang Penanganan Tindak Pidana Ringan (Tipiring) menegaskan bahwa setiap tindak pidana yang terjadi di berbagai wilayah hukum NKRI harus ditangani secara konsisten dan konsekuen termasuk tindak pidana ringan guna menjamin adanya kepatuhan dan ketaatan hukum.

Dalam lembaga Kepolisian penanganan tindak pidana ringan berpatokan pada Peraturan Kepala Badan Pemelihara Keamanan Kepolisian Negara Republik Indonesia Nomor 6 Tahun 2011 Tentang Penanganan Tindak Pidana Ringan (selanjutnya disebut perkabaharkam) yang terbit sebelum Peraturan Mahkamah Agung No 2 Tahun 2012 Tentang Penyesuaian Batasan Tindak Pidana Ringan dan Jumlah Denda Dalam KUHP (selanjutnya disebut Perma) di sahkan, peraturan tersebut sama-sama membahas tentang tindak pidana ringan, Dalam Perkabaharkam membahas tentang penanganan tindak pidana ringan yang dilakukan oleh Satuan Samapta dalam lembaga kepolisian yang berlaku dan digunkanan hingga saat ini, terlebih daripada itu peraturan terkait penanganan tindak pidana ringan dalam lembaga Kepolisian sampai sekarang belum diberbarui secara tersendiri.

Dalam lembaga Kepolisian Polres Labuhan Batu Beserta Polsek Sejajaran terdapat penyesuaian penanganan Tindak Pidanayang dirujuk pada PERMA No 2 Tahun 2012 yang awalnya tindak pidana tersebut tidak efektif dikarenakan nominal kerugian yang di cantumkan ialah Rp. 250 sebelum PERMA No 2 Tahun 2012 lahir, secara otomatis setelah lahir PERMA No 2 Tahun 2012 tindak pidana yang disebutkan yang awalnya bernominal kerugian lebih dari Rp. 250 yang ditangani oleh satuan Reskrim akan menyesuaiakan penanganannya menjadi ditangani oleh satuan samapta, Sat Samapta sendiri melakukan penanganan tindak pidana ringan dengan berpedoman pada Peraturan Kepala Badan Pemelihara Keamanan Kepolisian Negara Republik Indonesia Nomor 6 Tahun 2011 Tentang Penanganan Tindak Pidana Ringan, pada intinya dalam peraturan tersebut penanganan tindak pidana ringan diperuntukkan terhadap perbuatan pelanggaran dan memandang tindak pidana ringan sebagai perkara yang jarang masuk dengan demikian peralihan penangan tersebut tidak menutup kemungkinan bahwa penyidik samapta mengadaptasikan dirinya terhadap penerapan PERMA No 2 Tahun 2012.

\section{Implementasi Hukum Terhadap Tindak Pidana Pencurian Ringan Setelah Lahirnya Peraturan Mahkamah Agung Nomor 02 Tahun 2012 Tentang Tindak Pidana Ringan}

Pencurian Dalam Bentuk Pokok. Pencurian di dalam bentuknya yang pokok itu diatur di dalam di Dalam Pasal 362 Kitab Undang-Undang Hukum Pidana yang berbunyi: Barangsiapa mengambil suatu benda, yang seluruhnya atau sebagian adalah kepunyaan orang lain, dengan 
maksud untuk menguasai benda tersebut secara melawan hak, maka ia dihukum karena salahnya melakukan pencurian dengan hukuman penjara selama-lamanya lima tahun atau denda setinggitingginya enam puluh rupiah.

Menurut Peraturan Pemerintah Nomor 18/1960, pidana denda itu harus dikalikan limabelas. Oleh karena itu pidana denda yang ada dalam Pasal 362 KUHP tersebut harus dibaca sembilan ratus rupiah. Membaca rumusan pasal tersebut segera dapat kita ketahui, bahwa kejahatan pencurian itu merupakan delict yang dirumuskan secara formal atau yang disebut juga sebagai delict met formele omschrijving, dimana yang dilarang dan diancam dengan hukuman itu adalah suatu perbuatan yang dalam hal ini adalah perbuatan mengambil atau wegnemen.

Pengertian Pencurian Ringan dalam KUHP. Pencurian ringan atau yang disebut juga "gepriviligieerde diefstal" itu diatur di dalam Pasal 364 Kitab Undang-Undang Hukum Pidana. Yang dimaksud dengan gepriviligieerde diefstal itu adalah perbuatan pencurian yang memiliki unsurunsur dari pencurian di dalam bentuknya yang pokok, dan karena ditambah dengan unsur-unsur yang meringankan, ancaman hukumannya menjadi diperingan.

Tidak ada kesulitannya untuk mengetahui secara tepat apa yang diatur di dalam Pasal 364 Kitab Undang-Undang Hukum Pidana tersebut, kecuali untuk memudahkan bagi para pembaca, penulis sebutkan bahwa ini unsur-unsur dari kejahatan tersebut. Pencurian di dalam bentuknya yang meringankan; Tidak dilakukan oleh dua orang atau lebih secara bersama-sama; Tidak dengan pembongkaran, perusakan, pemanjatan, kunci palsu, perintah palsu ataupun seragam pa lsu. Pencurian seperti itu disebut pencurian ringan, jika: Proses Penyelesaian Tindak Pidana Pencurian Ringan Menurut Peraturan Mahkamah Agung No. 02 Tahun 2012.

Menurut Pasal 7 jo. Pasal 8 UU Pembentukan Peraturan Perundang-undangan telah mengatur tata urutan peraturan perundang-undangan di Indonesia bahwa Perma diakui sebagai salah satu bentuk peraturan perundang-undangan di Indonesia. Pembentukan Perma Nomor 02 Tahun 2012 dibentuk berdasarkan kewenangan. Mahkamah Agung berwenang untuk mengeluarkan peraturan, yaitu Perma. Alasan Mahkamah Agung RI untuk mengeluarkan Perma Nomor 02 Tahun 2012 ini dituangkan pada bagian "menimbang" sebagai berikut: Bahwa sejak tahun 1960 seluruh nilai uang yang terdapat dalam KUHP belum pernah disesuaikan kembali;

Bahwa apabila nilai uang yang ada dalam KUHP tersebut disesuaikan dengan kondisi saat ini maka penanganan perkara tindak pidana ringan seperti pencurian ringan, penipuan ringan, penggelapan ringan, dan sejenisnya dapat ditangani secara proporsional mengingat ancaman hukuman paling tinggi yang dapat dijatuhkan hanyalah tiga bulan penjara, dan terhadap tersangka atau terdakwa tidak dapat dikenakan penahanan, serta acara pemeriksaan yang digunakan adalah Acara Pemeriksaan Cepat; Bahwa perubahan KUHP akan memakan waktu yang cukup lama sementara perkara-perkara terus masuk ke pengadilan; Bahwa sejak tahun 1960 nilai rupiah telah mengalami penurunan sebesar kurang lebih 10.000 kali jika dibandingkan harga emas pada saat ini.

\section{Kendala Aparat Penegak Hukum (Kepolisian) Dalam Penegakan Hukum Terhadap Tindak Pidana Pencurian Ringan Berdasarkan Peraturan Mahkamah Agung Nomor 02 Tahun 2012}

Mewujudkan penegakan hukum yaitu untuk memperoleh kepastian hukum, keadilan, dan manfaat dari penegakan hukum tersebut. Proses penegakan hukum dapat berjalan dengan efektif apabila terbentuk suatu mata rantai beberapa proses yang tidak boleh di pisahkan antara lain: penyidikan, tuntutan jaksa, vonis hakim dan pembuatan peraturan perundang-undangan. Namun pada kenyataanya penegakan hukum penerapan Peraturan Mahkamah Agung No. 2 Tahun 2012 mengalami beberapa kendala atau hambatan yang dipengaruhi oleh beberapa faktor-faktor. Dengan demikian terdapat masalah dalam penegakan hukum, menurut Soerjono Soekamto, antara lain faktor hukumnya sendiri, faktor penegak hukum, faktor sarana atau fasilitas yang mendukung penegakan hukum, faktor masyarakat, dan faktor kebudayaan.

Kendala yang dihadapi pihak Kepolisian dalam menangani proses penyidikan tindak pidana pencurian ringan terbagi menjadi kendala dua yaitu, (1) Kendala internal, yang termasuk ke dalam kendala internal adalah sebagai berikut: sarana dan prasana kurang memadai, jaringan informasi

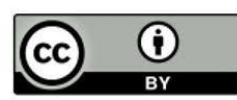


yang terputus, kurang memadainya anggota kepolisian dari segi kuantitas, kurang dukungan anggaran. (2) Kendala eksternal, seperti: kurangnya alat bukti dan saksi, masyarakat yang apatis dalam membantu pihak kepolisian, sarana pendukung pada tempat kejadian perkara kurang memadai.

Kendala yang timbul dalam implementasi Perma Nomor 2 Tahun 2012 dalam penanganan tindak pidana pencurian ringan di Polres Labuhan Batu adalah sebagai berikut: Kurangnya Pemahaman Pihak Kepolisian Terhadap Perma Nomor 2 Tahun 2012; Penerapan PERMA Nomor 2 Tahun 2012 mengenai perbuatan yang dilakukan secara berulang-ulang; Keberanian Pihak Kepolisian dalam menindak tindak pidana dengan tidak tumpang tindih; Sosialisasi Kepada Aparat; Kultur di Masyarakat.

\section{Upaya Yang Dilakukan Oleh Aparat Penegak Hukum (Kepolisian) Dalam Pelaksanaan Peraturan Mahkamah Agung No. 2 Tahun 2012}

Upaya dalam pelaksanaan faktor hukumnya sendiri/Substansi hukum yang akan ditegakkan. Perbaikan penegakan hukum dapat dimulai dari substansi hukum. Substansi hukum di Indonesia banyak dipengaruhi oleh kepentingan politik, bahkan juga oleh kepentingan dunia usaha. Sejarah Indonesia menunjukan bahwa buruknya substansi hukum di Indonesia disebabkan oleh sistem politik yang tidak demokratis. Itulah sebabnya, langkah penting yang ditempuh adalah mengubah struktur politik menuju ke arah yang lebih demokratis, dengan alasan bahwa tidak mungkin ditegakkan hukum di dalam sistem politik yang tidak demokratis.

Upaya dalam pelaksanaan Faktor Penegak Hukum. Dalam rangka peningkatan upaya pelaksanaan dan penegakan hukum baik bagi masyarakat maupun aparat penegak hukum itu sendiri, maka pemerintah Negara RI telah melakukan pembaharuan terhadap beberapa peraturan untuk memperbaiki sistem hukum yang ada demi tercapainya masyarakat yang adil dan tentram, dengan adanya perbaikan peraturan bagi para aparat penegak hukum maka masing-masing pihak diharapkan dapat melaksanakan tugas, fungsi dan wewenangnya masing-masing secara bertanggung jawab, pelaksanaan tersebut tidak lepas dari pengawasan pemerintah dan masyarakat.

Upaya dalam meningkatkan Faktor Sarana atau Fasilitas. Pada elemen ketiga, tersedianya fasilitas yang berwujud sarana dan prasarana bagi aparat pelaksana di dalam melakukan tugasnya. Sarana dan prasarana yang dimaksud adalah prasarana atau fasilitas yang digunakan sebagai alat untuk mencapai efektifitas hukum.

Upaya yang dilakukan terhadap faktor peran masyarakat. Faktor masyarakat yaitu merupakan lingkungan hukum tersebut berlaku atau diterapkan. Penegakan hukum itu berasal dari masyarakat dan bertujuan untuk mencapai kedamaian dalam masyarakat. Oleh karena itu masyarakat dapat mempengaruhi penegakan hukum.

Upaya yang dilakukan terhadap Faktor Kebudayaan. Program ini bertujuan untuk meningkatkan kembali kesadaran dan kepatuhan hukumbaik bagi masyarakat maupun aparat penyelenggara negara secara keseluruhan dan meningkatkan tingkat kepercayaan masyarakat terhadap peran dan fungsi aparat penegak hukumyang diharapkan akan menciptakan budaya hukum yang baik di semua lapisan masyarakat.

\section{Upaya Aparat Penegak Hukum (Kepolisian) Berdasarkan Perma Nomor 2 Tahun 2012 Dalam Penanganan Tindak Pidana Pencurian Ringan Di Polres Labuhan Batu}

Kurangnya Pemahaman Pihak Kepolisian Terhadap Perma Nomor 2 Tahun 2012. Upaya pemahaman Polri dalam pelaksanaan Perma Nomor 2 Tahun 2012 dan mendukung pemerintahan yang baik dan bersih, maka penyelenggaraan fungsi Kepolisian harus mencapai tujuan nasional sebagai perwujudan dan falsafah atau idiologi negara yang selalu menjadi acuan bagi tujuan Kepolisian. Pada setiap anggota kepolisian dalam mencapai tujuan senantiasa menjiwai dan mewarnai sikap, prilaku yang baik, sehingga dapat membentuk jati diri yang diwujudkan dalam konsepsi Kepolisian. 
Penerapan Perma Nomor 2 Tahun 2012 mengenai perbuatan yang dilakukan secara berulang-ulang. Upaya yang dilakukan dalam mengatasi kendala penerapan Perma No. 2 Tahun 2012 mengenai perbuatan yang dilakukan secara berulang-ulang adalah tindakan aparat penegak hukum yang dilakukan secara aktif agar kejahatan yang sering terjadi dapat berkurang. Upaya tersebut dilakukan sebagai bentuk penanganan yang dilakukan oleh aparat penegak hukum demi bekerjanya sistem peradilan pidana untuk menanggulangi kejahatan dan mencegah agar pelaku kejahatan pencurian ringan tidak lagi mengulangi kejahatannya lagi.

Keberanian Pihak Kepolisian dalam menindak tindak pidana dengan tidak tumpang tindih. Peran aparatur penegak hukum di dalam kerangka sistem peradilan pidana khususnya penyidik sangat strategis. Penyidik merupakan pintu gerbang utama dimulainya tugas pencarian kebenaran materiil karena melalui proses penyidikan sejatinya upaya penegakan hukum mulai dilaksanakan. Penyidikan merupakan suatu tahap terpenting dalam kerangka hukum acara pidana di Indonesia karena dalam tahap ini pihak penyidik berupaya mengungkapkan fakta-fakta dan bukti-bukti atas terjadinya suatu tindak pidana serta menemukan tersangka pelaku tindak pidana tersebut.

Sosialisasi Kepada Aparat. Menurut Deswin A Sirait upaya yang dilakukan pihak Kepolisan Resor Labuhan Batu dalam meingkatkan kesadaran pemahaman kepada aparat Kepolisian dalam rangka pemahaman aturan hukum yang baru di kalangan Kepolisian sehingga aparat Kepolisian benar-benar menguasai setiap kebijakan yang diberlakukan agar dalam penerapannya tidak terkendala. Upaya peningkatan pemahaman mengenai Perma Nomor 2 Tahun 2012 adalah melakukan Sosialisasi rutin kepada aparat Kepolisian yang bertugas di Kantor Kepolisian resor Labuhan Batu mengenai pemahaman yang diberikan adalah tentang penyesuaian batasan tindak pidana ringan.

Kultur di Masyarakat. Untuk mengatasi kendala dalam kultur budaya masyarakat dan menjangkau perubahan-perubahan sosial yang sangat dinamis di dalam masyarakat, perkembangan sistem penegakan hukum di Indonesia pada akhirnya harus mengikuti perubahan pola pikir dan budaya hukum yang ada saat ini. Hukum harus menyediakan ruang toleransi yang memungkinkan para anggota masyarakat dan para penegak hukum bergerak secara lebih leluasa mengikuti gerak dinamika masyarakat.

\section{SIMPULAN}

Berdasrkan hasil penelitian tentang Akibat Hukum Berlakunya Perma Nomor 02 Tahun 2012 Tentang Penyesuaian Batasan Tindak Pidana Pencurian Ringan Dan Jumlah Denda Dalam KUHP, maka dapat ditarik kesimpulan sebagai berikut Kaidah hukum batasan tindak pidana ringan dan jumlah denda dalam KUHP dengan lahirnya Peraturan Mahkamah Agung Nomor 02 Tahun 2012 yaitu: Kedudukan Hukum Peraturan Mahkamah Agung Nomor 2 Tahun 2012 secara substansi adalah berkaitan penyesuaian batasan tindak pidana ringan dan jumlah denda di dalam Peraturan Mahkamah Agung Nomor 2 Tahun 2012. Implementasi hukum terhadap tindak pidana pencurian ringan setelah lahirnya Peraturan Mahkamah Agung Nomor 02 Tahun 2012 tentang tindak pidana ringan adalah sebagai berikut: Keberadaan Perma No. 2 Tahun 2012 adalah sebagai Kebijakan Kriminal dan selama ini kebijakan kriminal dipahami sebagai ranah Sistem Peradilan Pidana (SPP) yang menerapkan reprentasi dari negara. Kendala yang dihadapi oleh aparat penegak hukum (kepolisian) dalam penegakan hukum terhadap tindak pidana ringan berdasarkan Peraturan Mahkamah Agung Nomor 02 Tahun 2012. Kendala dalam penegakan hukum terjadi apabila ada ketidakserasian antara pasangan nilai dan ketidakserasian ini bisa disebabkan oleh: Faktor hukumnya sendiri (Undang-Undang), Faktor penegak hukum yakni pihak-pihak yang membentuk maupun menetapkan hukum, Faktor sarana atau fasilitas yang mendukung penegakan hukum, Faktor masyarakat, yakni lingkungan di mana hukum tersebut berlaku dan diterapkan, Faktor kebudayaan, yakni sebagai hasil karya, cipta dan rasa didasarkan pada keras manusia dalam pergaulan hidup.

\footnotetext{
106 http://mahesainstitute.web.id/ojs2/index.php/jehss mahesainstitut@gmail.com 


\section{DAFTAR PUSTAKA}

Achjani, E. (2017). Perkembangan Sistem Pemidanaan dan Sistem Pemasyarakatan. Depok: Rajawali Pers.

Asmah. (2018). Pengantar Hukum Indonesia Suatu Pemahaman Awal Mengenal Hukum. Yogyakarta: UII Press.

Batu, F.L., Siregar, T. \& Muazzul. (2020). Peranan Kepolisian Dalam Memberantas Tindak Pidana Pencurian Dengan Kekerasan Di Wilayah Patumbak (Studi Kasus Di Polsek Patumbak). JUNCTO, 2(1) 2020: 68-77

Chaerudin. (2009). Strategi Pencegahan dan Penegakan Hukum Tindak Pidana Korupsi. Bandung: Refika Aditama.

Ediwarman. (2014). Penegakan Hukum Pidana Dalam Perspektif Kriminologi. Yogyakarta: Genta Publishing.

Hananta, D. (2017). Menggapai Tujuan Pemidanaan Dalam Perkara Pencurian Ringan. Bandung: Mandiri Maju.

Herman, U., Din, M., \& Ali, D. (2018). Kekuasaan Pengaturan Mahkamah Agung Tentang Batasantindak Pidana Ringan dan Jumlah Denda dalam KUHP dalam Sistem Hukum Pidana. Syiah Kuala Law Journal, 2(2), 301-319.

https//businesslaw.binus.ac.id/2018/12/26/penegakan-hukum-masalahnya-apa/, diakses pada tanggal 16 Maret 2021, pada pukul 21.30. Wib.

https//ekampushukum.blogspot.com/2016/05/akibat-hukum.html, diakses pada tanggal 2 Januari 2021, pada pukul 18.50 Wib.

https//tribratanews.kepri.polri.go.id/2019/12/30/pengaturan-tindak-pidana-ringan-dalam-kuhp/ diakses pada tanggal 2 Januari 2021, pada pukul 18.30 Wib.

https//www.bappenas.go.id/files/3013/5228/3483/bab-iii-pembangunan hukum. pdf,diakses pada tanggal 20 Maret 2021, pada pukul 22.00. Wib.

Noviansyah, R., Rifai, E., \& Dewi, E. (2018). Penegakkan Hukum Penerapan Peraturan Mahkamah Agung Nomor 2 Tahun 2012 Tentang Penyesuaian Batasan Tindak Pidana Ringan dan Jumlah Denda dalam KUHP. Diaspora: Sosiohumaniora, 1(2), 117-130.

Nurhaini, E. (2018). Metode Penelitian Hukum Langkah-langkah untuk Menemukan Kebenaran dalam Ilmu Hukum. Bandung: Refika Aditama.

Peraturan Kepala Kepolisian Negara Republik Indonesia No. 6 Tahun 2019 tentang Penyidikan Tindak Pidana.

Peraturan Mahkamah Agung (Perma) No 2 Tahun 2012 tentang Penyelesaian Batasan Tindak Pidana Ringan (Tipiring) dan Jumlah Denda dalam KUHP.

Prodjodikoro, W. (2012). Tindak-tindak Pidana Tertentu di Indonesia. Bandung: Refika Aditama.

Purba, J. (2017). Penegakan Hukum Terhadap Tindak Pidana Bermotif Ringan dengan Restorative Justice. Jakarta: Jala Permata Aksara.

Rumokoy, D. A. (2017). Pengantar Ilmu Hukum. Jakarta: PT. Raja Grafindo Persada.

Saleh, R. (1983). Hukum Pidana Sebagai Konfrontasi Manusia dan Manusia. Jakarta: Ghalia Indonesia.

Sianturi, J.E., Marlina., \& Siregar, T. (2020). Politik Hukum Pidana Terhadap Penanganan Tindak Pidana Pencurian Dengan Kekerasan Yang Terjadi Di Jalanan Kota Medan ( Studi Di Kota Medan). ARBITER: Jurnal Ilmiah Magister Hukum. 2(1): 62-73.

Sinaga, D. (2017). Penegakan Hukum Dengan Pendekatan Diversi. Yogyakarta: Nusa Media.

Yasin, M. (2014). Panduan Bantuan Hukum di Indonesia. Jakarta: Yayasan Obor Indonesia.

Zulyadi, R. (2020). Kerangka Teori Dalam Penelitian Hukum. Medan: Enam Media.

Undang-Undang Dasar Negara Republik Indonesia Tahun 1945.

Undang-Undang Indonesia No. 2 Tahun 2002 tentang Kepolisian Negara Republik Indonesia.

Undang-Undang Indonesia No. 8 Tahun 1981 tentang Hukum Acara Pidana.

Undang-Undang Republik Indonesia No. 1 Tahun 1946 tentang Peraturan Hukum Pidana. 